\title{
COMPARATIVE CALCULATION OF HEAT EXCHANGE WITH THE GROUND IN RESIDENTIAL BUILDING INCLUDING PERIODES OF HEAT WAVES
}

\author{
Anna STASZCZUK ${ }^{1}$, Tadeusz KUCZYŃSKI ${ }^{2}$, Magdalena WOJCIECH ${ }^{3}$, \\ Piotr ZIEMBICKI ${ }^{4}$ \\ University of Zielona Góra, Zielona Góra, Poland
}

\begin{abstract}
The paper provides verification of 3D transient ground-coupled model to calculation of heat exchange between ground and typical one-storey, passive residential building. The model was performed with computer software WUFI ${ }^{\circledR}$ plus and carried out to estimate the indoor air temperatures during extending hot weather periods. For verifying the results of calculations performed by the $\mathrm{WUFI}^{\circledR}$ plus software, the most recent version of EnergyPlus software version was used. Comparison analysis of calculation results obtained with the two above mentioned calculation method was made for two scenarios of slab on ground constructions: without thermal insulation and with thermal insulation under the whole slab area. Comprehensive statistical analysis was done including time series analysis and descriptive statistics parameters.
\end{abstract}

Keywords: transient calculation model, heat waves, ground heat storage, time series.

\section{INTRODUCTION}

Changes in Global climate and in consequence extended time of extremely hot weather [1], [2], [3], [4] may have very harmful effect on human life [5], thus significantly affecting the approach to thermal design of the building. For one-

1,2,4 Corresponding author: University of Zielona Góra, Faculty of Civil and Environmental Engineering, Z. Szafrana st 1, 65-516 Zielona Góra, Poland, e-mail: a.staszczuk@ib.uz.zgora.pl ${ }^{3}$ Corresponding author: University of Zielona Góra, Faculty of Mathematics, Computer Science and Econometrics, Z. Szafrana st 1, 65-516 Zielona Góra, Poland 
storey passive, residential buildings, the natural choice seems to be applying a phenomena of floor - ground thermal coupling which allows for benefitting of unlimited ground heat storage capacity in the summer for cooling the inside air. To that end Staszczuk and Kuczyński [6] presented original solution and suggested to resign completely or partially from ground slab thermal insulation, directly utilizing ground heat storage capacity. Three dimensional transient ground-coupled model performed with WUFI ${ }^{\circledR}$ plus software was used to estimate the air temperatures inside the buildings during heat waves.

The main goal of the paper was to verification of above mentioned calculation model by the other one performed with widely recognized Energy Plus software, including comparison and statistical analysis of calculation results for two scenarios of slab on ground constructions.

\section{CALCULATION TOOLS}

\subsection{Simulation with WUFI $^{\circledR}$ plus software}

WUFI ${ }^{\circledR}$ plus software was developed in Fraunhofer Institute for Building Physics IBP in Holzkirchen, Germany. The software was detailed presented by Staszczuk and Kuczyński [6].

In the paper 3-dimensional heat exchange between building and the ground is considered. To solve this problem, the software was supplemented by so called "3D objects". At certain distance from the building (at least half of a width and at least half of a length) a vertical adiabatic surface (with no horizontal heat flow) is assumed. Horizontal adiabatic surface (with no vertical heat flow) is assumed at $10 \mathrm{~m}$ below floor level (at this level ground temperature is assumed to be equal to average outdoor air temperature).

Finite volume method [7] was used to solve differential equations. Heat transferring space is divided into small control volumes with nodes inside their centres of gravity. Division of heat conducting space into balance-differential elements with variable grid is performed automatically by the program. Parameters of outdoor climate define first kind of boundary conditions on the upper surface of modeled ground. Heat exchange on the internal surface of the assemblies (wall, ceiling, floor) defines indoor boundary conditions (third kind boundary condition). Values of internal surface coefficient were assumed according to EN ISO 6946 [8].

To obtain realistic predictions of the indoor air temperature, the buildings were calculated with full thermal coupling with the ground. Indoor air temperature was obtained iteratively from heat balance of conditioned zone. The energy balance consists of heat exchange with thermal envelope including floor, 
ventilation, solar and internal gains according to EN-ISO 13790 [9]. Thermal coupling is established by defining of indoor air as a boundary condition for floor inside the building. Heat exchange with this assembly is attributed to zone air node. Transient heat flow calculations were made for 2 years period. First year of simulation was used only to define proper initial condition (temperature distribution) in the ground and was not taken into account. The "3D Objects" model was validated by Antretter et al. [10].

\subsection{Simulation with EnergyPlus software}

For verifying the results of calculations performed by the WUFI ${ }^{\circledR}$ plus software, which has not been yet widely recognized, the most recent EnergyPlus software, allowing for precise simulation of ground coupled heat transfer related to slabon-grade construction [11] was used.

The choice of the EnergyPlus software as a simulation engine was caused by the high quality of the results of calculations and a high level of flexibility in model development, which allow for the analysis of the assumption underlying the hereby publication. EnergyPlus was created on the basis of BLAST developed by the U.S. Department of Defense and DOE-2 developed by the U.S. Department of Energy [12], [13]. Both above mentioned applications in its early versions were designed for the purpose of calculation of heat demand and dedicated to architects and engineers specializing in design, modernization, cost analysis and optimization of energy consumption in building including HVAC and installations. Just like its predecessors, EnergyPlus is a software designed for the purpose of analyzing energy balance of buildings, extended by the options of detailed simulation of heat load and annual energy consumption as well as other functionalities related to the simulation of fixing installations in buildings. Just like in the case of WUFI ${ }^{\circledR}$ plus software, the climactic data such as external temperature, speed and direction of wind as well as exposure to the sun were implemented in EnergyPlus.

The calculation methodology implemented in the EnergyPlus calculation engine is analogous to the one used in WUFI ${ }^{\circledR}$ plus software. EnergyPlus program calculated ground temperatures for given time steps by means of 3D numerical analysis described by Bahnfleth in [14] and Deru in [15]. The modeling involves such significant elements as ground thermal conductivity, floor area and perimeter, ground surface parameters as well as shadowing of the ground adjacent to the analyzed object. The calculations are performed by means of 3dimensional thermal conductivity equations solved by procedures written in FORTRAN using the SIMPLE method developed by Patankar and Spalding [16]. The three-dimensional discretization network is divided into the maximum of 10 thousand cells, with the $0.1 \mathrm{~m}$ minimum distance between the cells. 
The fact that EnergyPlus is one of the best widely tested simulation models on the market, constituted a crucial criterion in the choice of this software as an application verifying the results of modeling.

On the basis of the data obtained from the software producer as well the results of the performer tests, it is possible to observe that EnergyPlus is also one of the best validated simulation programs available on the market.

The building model simulated in EnergyPlus was developed analogically as in the case of simulation by means of WUFI ${ }^{\circledR}$ plus software. The dimensions of the building, external temperatures, sun exposure as simulation scenarios are the same as in the case of the basic model. In view of such assumptions, the results obtained can be compared and analyzed with the results obtained in the model developed by means of the WUFI ${ }^{\circledR}$ plus software.

\section{ASSUMPTIONS}

\subsection{Scenarios}

Two scenarios of slab on ground constructions were considered:

- Scenario A: $15 \mathrm{~cm}$ concrete slab on ground without thermal insulation,

- Scenario B: $15 \mathrm{~cm}$ concrete slab on ground with thermal insulation $(30 \mathrm{~cm}$ EPS) under the whole slab area.

In each scenarios $1 \mathrm{~m}$ of vertical thermal insulation of foundation walls were applied (15 cm concrete and $30 \mathrm{~cm}$ EPS).

\subsection{Building and ground characteristics}

For simplicity of calculations one-storey passive residential building was considered in this paper. In the Table 1 and 2 construction assemblies and windows are presented respectively.

Table 1. Basic data of applied assemblies

\begin{tabular}{|c|c|c|c|}
\hline Building component & Construction & Thickness [m] & $\begin{array}{l}\text { U-value } \\
{\left[\mathrm{Wm}^{-2} \mathrm{~K}^{-1}\right]}\end{array}$ \\
\hline $\begin{array}{c}\text { Outer wall } \\
\text { / Internal wall }\end{array}$ & $\begin{array}{l}\text { Lightweight timber } \\
\text { framed wall (OSB } \\
\text { plate }+ \text { mineral wool) }\end{array}$ & $0.45 / 0.22$ & $0.10 / 0.22$ \\
\hline Slab on ground & Concrete + EPS & 0.45 & 0.13 \\
\hline $\begin{array}{c}\text { Foundation wall - 1m } \\
\text { deep }\end{array}$ & Concrete + EPS & 0.27 & 0.13 \\
\hline $\begin{array}{c}\text { Ceiling up to unheated } \\
\text { attic }\end{array}$ & $\begin{array}{c}\text { Lightweight ceiling } \\
\text { (OSB plate } \\
+ \text { mineral wool }\end{array}$ & 0.23 & 0.14 \\
\hline
\end{tabular}


Table 2. Windows ${ }^{*}$

\begin{tabular}{|c|c|}
\hline Orientation & Total area $\left[\mathrm{m}^{2}\right]$ \\
\hline $\mathrm{N}$ & - \\
\hline $\mathrm{S}$ & 4.80 \\
\hline $\mathrm{W}$ & 5.40 \\
\hline $\mathrm{E}$ & 8.04 \\
\hline
\end{tabular}

* Triple glazing windows SHGC (av.) $=0.53, \mathrm{U}=0.80 \mathrm{Wm}^{-2} \mathrm{~K}^{-1}$

\subsection{Weather data analysis}

The average temperatures of July, the warmest month in Poland, are within a range from approximately $17{ }^{\circ} \mathrm{C}$ in Baltic Coast to $19.3^{\circ} \mathrm{C}$ at its hottest part, the Silesian Lowland and Tarnow. The Polish cities with the longest periods of summer high temperature are Tarnow, Wroclaw, and Słubice with statistically 8 days in a month when maximum temperature exceeds $30^{\circ} \mathrm{C}$. Słubice is a small city located just at the western Polish border with Brandenburg, Germany. The period selected for analysis was described above [5], assuming a heat wave which took place in July 2006. At this month the maximum temperature at Słubice, measured at local meteorological station exceeded $30^{\circ} \mathrm{C}$ for 19 days and $33^{\circ} \mathrm{C}$ for 7 days. The average monthly air temperatures at Słubice in July was $23.8^{0} \mathrm{C} \pm 5.6^{\circ} \mathrm{C}$.

\section{RESULTS AND DISCUSSION}

In the paper the impact of slab on ground construction solution on indoor air temperature during the hottest period of 9 consecutive days in July 2006 at Słubice was analyzed in two scenarios of slab on ground construction and no other measures, as lack of thermal slab insulation, to cool down the indoor air temperature e.g. blinds in windows or increased night ventilation were used.

The comparison analysis of calculation results obtained with the WUFI ${ }^{\circledR}$ plus and EnergyPlus softwares are presented in Figure 1 and 2 for Scenario A and Scenario B respectively.

Comparing the plots of the temperatures obtained with WUFI $^{\circledR}$ plus and EnergyPlus in each scenarios we observe the daily cycle (seasonality) in both types of time series as well as similar pattern (Fig. 1,2). Moreover in each scenario appear similar trends over time.

In order to compare the distance between two time series WUFI ${ }^{\circledR}$ plus and EnergyPlus, the values of the dynamic time warping (DTW) were calculated. The DTW distance in scenario A was 61.26 and 46.17 in scenario B. 


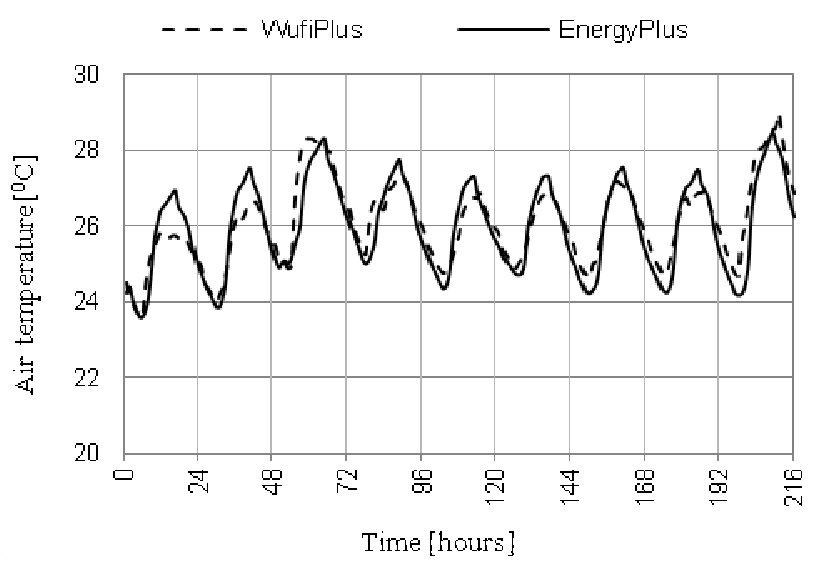

Fig. 1. Indoor air temperature in analyzed building for the hottest period of 9 days in July, 2006 at Słubice obtained with WUFI ${ }^{\circledR}$ plus and EnergyPlus. Scenario A.

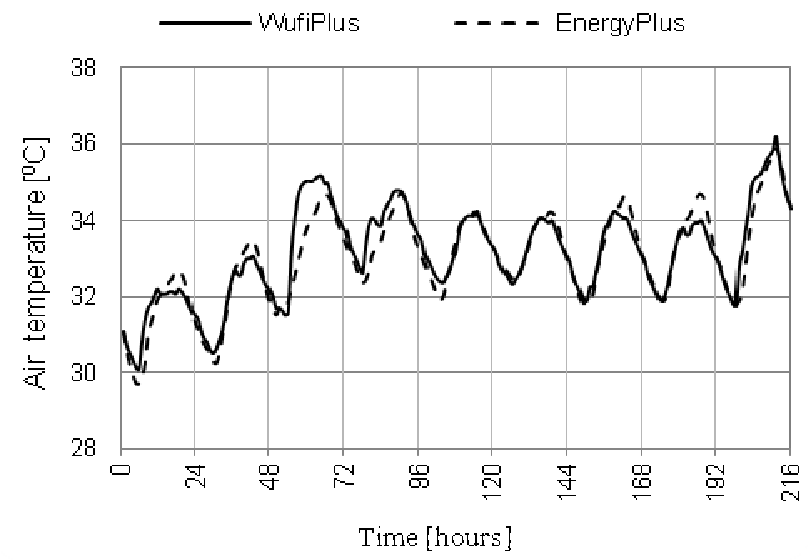

Fig. 2. Indoor air temperature in analyzed building for the hottest period of 9 days in July, 2006 at Słubice obtained with WUFI ${ }^{\circledR}$ plus and EnergyPlus. Scenario B.

The correlation graphs for the pairs of this temperatures (Fig. 3, 4) indicate high correlation in both analyzed scenarios. Moreover in the scenario A the residual mean square error was 0.47 and in scenario B was 0.41 . It implies stronger linear dependence (relations) between the indoor air temperature obtained with WUFI $^{\circledR}$ plus and EnergyPlus in scenario B.

In order to compare the results obtained with the methods presented in this article, the time series of paired differences between the temperatures obtained with EnergyPlus and WUFI ${ }^{\circledR}$ plus were defined (Fig. 4). 

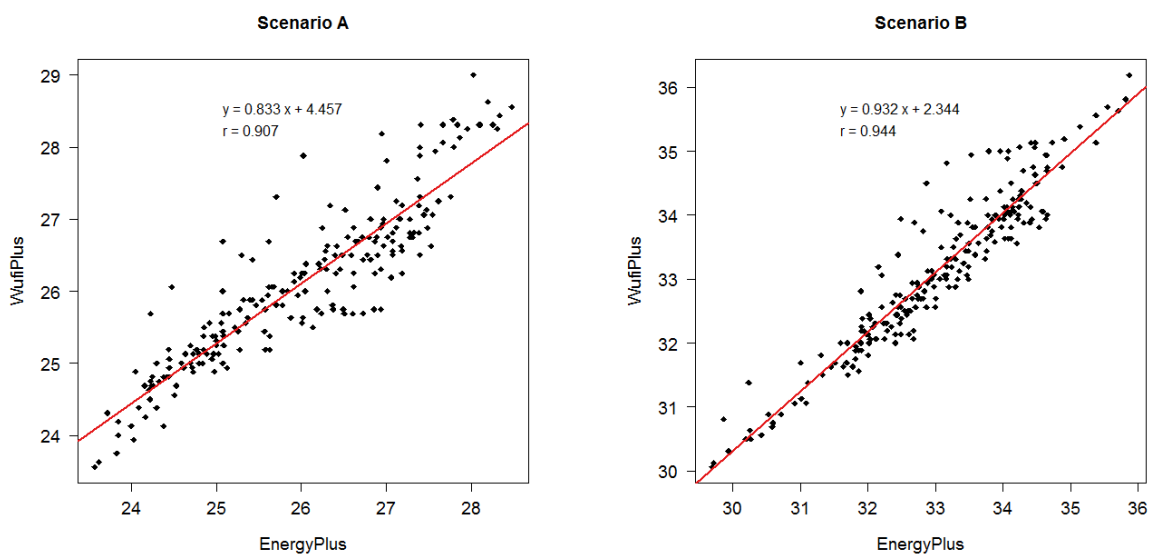

Fig. 3. Correlation between the temperatures obtained with $\mathrm{WUFI}^{\circledR}$ plus and EnergyPlus.

Calculations by R 3.1.0 [18].

The smooth locally-weighted polynomial regression ("lowess" curve) on a scatter diagram indicates, that in scenario A these differences vary with time more than in scenario B. In scenario A it is possibly the trend differences between the temperatures - it seems to be a slow downward trend. In both cases, but especially in scenario A, seasonal variation in the differences over time was observed. There is possibly a day cycle (Fig. 4, 5).
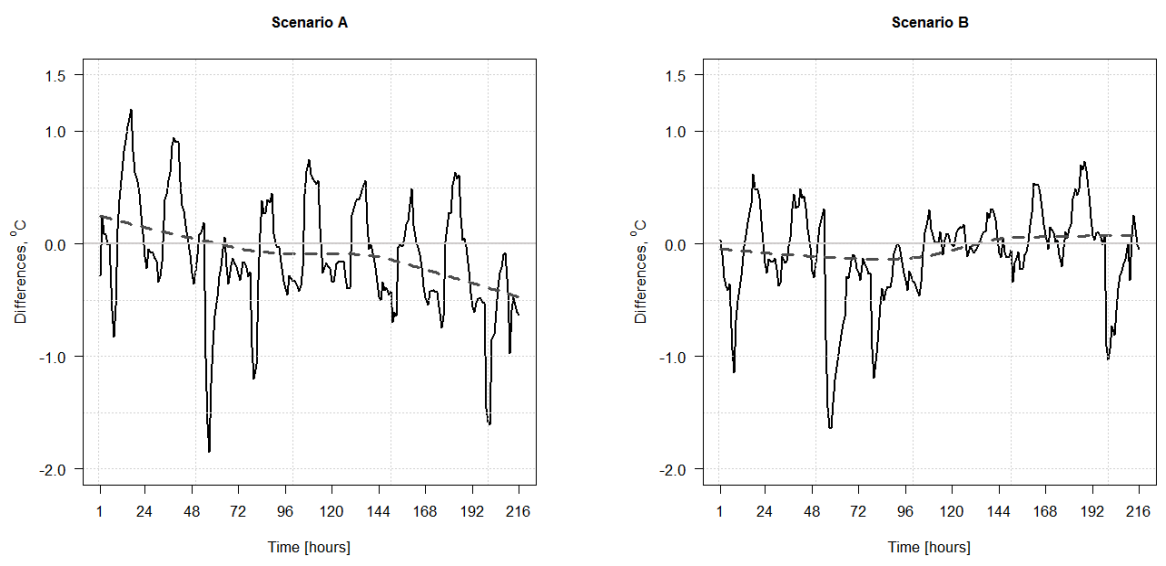

Fig. 4. The time plots of the paired differences between the temperatures obtained with EnergyPlus and WUFI®plus. Calculations by R 3.1.0 [18].

The boxplots presented in Figure 5 shows, that the range of the entire series of differences in scenario $\mathrm{B}\left(-1.64^{\circ} \mathrm{C}, 0.73^{\circ} \mathrm{C}\right)$ is smaller than in scenario A ($1.85^{\circ} \mathrm{C}, 1.19^{\circ} \mathrm{C}$ ). In both cases it is evident, that the variance of these differences of temperatures is changing over the time of day. Moreover it appears, that in 
scenario $\mathrm{B}$ these differences are more often near $0^{0} \mathrm{C}$ than in scenario $\mathrm{A}$, in which the differences are exhibiting more dynamic changes during the day.
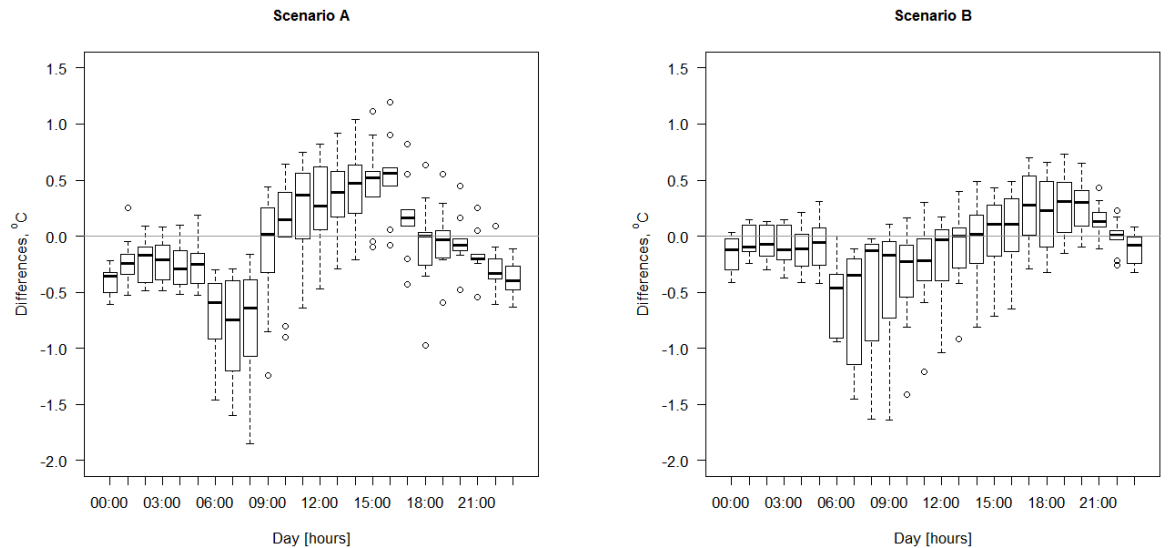

Fig. 5. The boxplots of 24-hour paired differences between the temperatures obtained with EnergyPlus and WUFI ${ }^{\circledR}$ plus. Calculations by R 3.1.0 [18]

In both scenarios the differences in temperatures have significant long-term effect that may be connected with the seasonal changes in the temperatures during the day (Fig. 6).
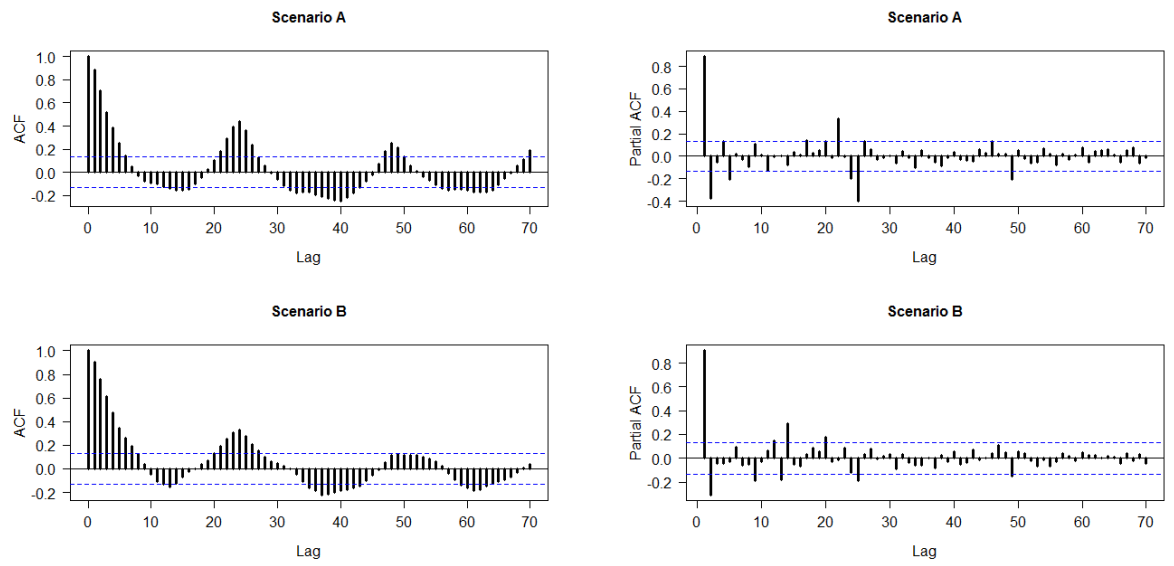

Fig. 6. The correlogram (ACF) and the partial autocorrelation function of the differences between temperature calculated with EnergyPlus and WUFI ${ }^{\circledR}$ plus . The dashed lines (the 95\% confidence limits: $\pm 1.96 / \sqrt{\mathrm{n}}$ ) represent the range outside which autocorrelation is statistically significant at the 0.05 level. Top frames are for A scenario and the bottom frames are for scenario B. Calculations by R 3.1.0 [18] 
Two presented correlograms show strong autocorrelation. This is to be expected due to the non-stationary nature of these time series, there may exist seasonal effect.

The autocorrelation values exceed the $95 \%$ confidence intervals at a few lags. In both scenarios the partial ACF plot indicates that there is strong and positive first autocorrelation. It shows that this differences of temperatures in one time period depend on those at the previous period of time. In both scenarios the autocorrelation sequence of the differences doesn't look like the autocorrelation sequence of a white noise process.

\section{CONCLUSIONS}

In the paper verification of 3D transient ground-coupled model to calculation of heat exchange between the ground in typical one-storey, passive residential buildings was performed with computer software $\mathrm{WUFI}^{\circledR}$ plus. The model was carried out to estimate the indoor air temperatures during heat waves was presented. For verifying the results of calculations performed by the WUFI ${ }^{\circledR}$ plus software, the most recent EnergyPlus software version was used. Detailed statistical analysis of calculation results obtained with both models was showed, that the results of the WUFI ${ }^{\circledR}$ plus method were similar to the ones obtained from the EnergyPlus. The distance measure for these time series and correlation analysis indicate, that especially in scenario B the differences between the temperatures obtained with this two programs were very small.

\section{REFERENCES}

1. Schär C., Jendritzky G.: Hot news from summer 2003, Nature, 432 (2004), 559-560.

2. De Bono, A., Giuliani G., Kluser S., Peduzzi P.: Impacts of summer 2003 heat wave in Europe, UNEP/DEWA/GRID-Europe Environment Alert Bulletin 2 (2004).

3. Hartz D. A., Golden J.S., Sister C., Chuang W.C., Brazel A. J.: Climate and heat-related emergencies in Chicago, Illinois (2003-2006), International Journal of Biometeorology, 56 (2012), 71-83.

4. Australia's National Climate Centre: The exceptional January-February 2009 heat wave in southeastern Australia, Bureau of Meteorology, Special Climate Statement 17 (2009).

5. Gabriel K., Endlicher R.W.: Urban and rural mortality rates during heat waves in Berlin and Brandenburg, Germany, Environmental Pollution 159 (2011), 2044-2050. 
6. Staszczuk A., Kuczyński T.:Effect of extending hot weather periods on approach to floor construction in moderate climate residential buildings (po pozytywnych recenzjach, w przygotowaniu do druku)

7. Eymard R., Gallouët T.R., Herbin R.: The finite volume method Handbook of Numerical Analysis, Vol. VII, 2000, 713-1020. Editors: P.G. Ciarlet and J.L. Lions.

8. EN ISO 6946:2007: Building components and building elements - Thermal resistance and thermal transmittance - Calculation Method.

9. EN-ISO 13790.2007: Energy performance of buildings - Calculation of energy use for space heating and cooling.

10. Antretter F., Radon J., Pazold M.: Coupling of dynamic thermal bridge and whole building simulation, Thermal Performance of the Exterior Envelopes of Whole Buildings, XII International Conference, ASHRAE, Clearwater/USA, 2013.

11. Henninger R. H., Witte M. J.: EnergyPlus testing with IEA BESTEST indepth ground coupled heat transfer tests related to slab-on-grade construction, EnergyPlus Version 8.1.0.009, November 2013, http://apps1.eere.energy.gov/buildings/energyplus/pdfs/energyplus_slab-ongrade_tests.pdf.

12. Andolsun S., Culp C. H., Haberl J., Witte M. J.: EnergyPlus vs.DOE-2.1e: The effect of ground-coupling on energy use of a code house with basement in a hot-humid climate, Energy and Buildings 43 (2011), 1663-1675.

13. Crawley D. B., Lawrie L. K., Winkelmann F. C., Buhl W. F., Huang Y. J., Pedersen C. O., Strand R. K., Liesen R. J., Fisher D. E., Witte M. J., Glazer $\mathrm{J} .:$ EnergyPlus: creating a new-generation building energy simulation program, Energy and Buildings 33 (2001), 319-331.

14. Bahnfleth W.P.: Three dimensional modeling of heat transfer from slab floors, Ph.D. Dissertation, University of Illinois (1989).

15. Deru M., Judkoff R., Neymark J.: Whole-Building energy with a threedimensional ground-coupled heat transfer model. Preprint. National Renewable Energy Laboratory, USA (2002).

16. Patankar S.V., Spalding D.B.: A calculation procedure for heat, mass and momentum transfer in three-dimensional parabolic flows. International Journal Heat Mass Transfer,15:1787-1806, 1972.

17. EN ISO 13370.2007: Thermal performance of buildings. Heat transfer via the ground. Calculation methods.

18. $\mathrm{R}$ Core Team: A language and environment for statistical computing. $R$ Foundation for Statistical Computing, Vienna, Austria, 2014.URL http://www.R-project.org/ 


\section{WERYFIKACJA NIESTACJONARNEGO MODELU DO OBLICZEŃ TEMPERATURY W JEDNORODZINNYCH BUDYNKACH MIESZKALNYCH PODCZAS FAL UPAŁÓW}

\section{Streszczenie}

$\mathrm{W}$ artykule przedstawiono weryfikację modelu 3D, będącego elementem programu komputerowego WUFI@plus do obliczeń niestacjonarnej wymiany ciepła budynku z termicznym sprzężeniem $\mathrm{z}$ gruntem. Za pomocą tego modelu oszacowano kształtowanie się temperatury wewnątrz jednorodzinnego, pasywnego budynku mieszkalnego podczas fali upałów. W celu weryfikacji przyjętego modelu zastosowano inny, bardziej rozpowszechniony model używany w programie komputerowym EnergyPlus. W artykule przedstawiono analizę porównawczą wyników obliczeń otrzymanych z zastosowaniem obu programów komputerowych dla dwóch wariantów konstrukcji podłogi na gruncie: bez izolacji termicznej oraz z izolacją termiczną pod płytą na całej jej powierzchni. Ponadto sporządzono analizą statystyczną otrzymanych wyników, uwzględniająca analizę szeregów czasowych oraz parametrów statystyki opisowej.

Słowa kluczowe: model do obliczeń niestacjonarnych, fale upałów, wymiana ciepła z gruntem, szeregi czasowe.

Editor received the manuscript: 12.01 .2016 